\title{
Factors controlling primary production and photosynthetic characteristics of intertidal microphytobenthos
}

\author{
Christiane Barranguet ${ }^{1,2, *}$, Jacco Kromkamp ${ }^{1}$, Jan Peene ${ }^{1}$ \\ ${ }^{1}$ Netherlands Institute of Ecology, Postbus 140, 4400 AC Yerseke, The Netherlands \\ ${ }^{2}$ University of Amsterdam, Department of Aquatic Ecology and Ecotoxicology, Kruislaan 320, 1098 SM Amsterdam, \\ The Netherlands
}

\begin{abstract}
Microphytobenthic primary production and biomass were studied in an intertidal flat located in the Westerschelde (SW Netherlands) with a vertical resolution of $1 \mathrm{~mm}$. Short-term variability of primary production and photosynthetic characteristics were compared during low tide in 2 types of sediment: sandy and muddy sands. The changes observed were compared with abiotic factors and the biomass abundance, which was dominated by benthic diatoms. ${ }^{14} \mathrm{C}$ uptake values obtained from incubations in a photosynthetron were used for the construction of P-I (photosynthesis-irradiance) curves. Annual averages indicate that both sediments were equally productive $\left(34.5 \pm 23.6 \mathrm{mg} \mathrm{C} \mathrm{m} \mathrm{m}^{-2}\right.$ $\mathrm{h}^{-1}$ and $41.1 \pm 11.6 \mathrm{mg} \mathrm{C} \mathrm{m} \mathrm{Ch}^{-1}$ for the sands and muddy sands respectively), but production rates were highly variable on monthly time scales and were regulated by different mechanisms. Light and temperature played an important role in determining the production rates, especially in the muddy sediments, where changes in $I_{k}$ (light saturation) were correlated with temperature. $I_{k}$ showed seasonal changes, suggesting that algae adapted to the seasonal light conditions but there was not a significant correlation between the $I_{k}$ and PAR (photosynthetic available radiation) at any of the stations. Vertical migration of the algae, as followed by spectroradiometric measurements, probably accounted for a general absence of photoinhibition. In the sandy sediments, production appeared to be limited by the low biomass of algae, due to resuspension and export. The fact that gross oxygen production rates measured on intact cores using microelectrodes were not lower than potential production obtained from ${ }^{14} \mathrm{C}$ fixation suggests that short-term limitation of production due to nutrients and/or carbon is nat frequent in the microphytobenthos of the Westerschelde.
\end{abstract}

KEY WORDS: Microphytobenthos - Photosynthetic characteristics · Primary production - Tidal flats

\section{INTRODUCTION}

The importance of benthic microalgae in shallow estuarine systems as oxygen producers, carbon fixers and food sources for grazers is now fully recognised and well documented (Heip et al. 1995 and references therein), but the mechanisms regulating microphytobenthos production on short time scales still need further study (Pinckney \& Zingmark 1993).

In intertidal sediments, the microphytobenthos community has to adapt to a series of stressful factors, such as sediment transport, as well as steep gradients in light, temperature and nutrient concentrations. In tur-

\footnotetext{
•E-mail: barranguet@bio.uva.nl
}

bid estuaries, microphytobenthos production will be mainly restricted to the emersion period due to light limitation during flood tide (Colijn 1982). In turbid environments, benthic microalgae can be the principal input of organic matter in tidal flats (MacIntyre et al. 1996 and references therein). In temperate estuaries, microphytobenthic biomass is fairly constant throughout the year. However, the production shows both steep seasonal peaks and large variations on hourly time scales (Barranguet 1997 and references therein). Photoacclimation and vertical migration are some of the mechanisms which might be responsible for these changes in photosynthetic activities.

Blanchard \& Cariou-Le Gall (1994) advocated the use of photosynthetic parameters (photosynthetic capacity and maximal photosynthetic efficiency) to 
better understand the mechanisms of adaptation of microphytobenthic algae to changing environmental conditions by photoacclimation.

We aimed to assess the rates of microphytobenthos production in a tidal flat of the Westerschelde (the Molenplaat, SW Netherlands) and the response of microalgal photosynthesis to environmental regulating factors. For that purpose, we used the photosynthetic parameters and production rates calculated from ${ }^{14} \mathrm{C}$ P-I (photosynthesis-irradiance) curves, and gross oxygen production rates estimated with oxygen microelectrodes. Both methods have their own advantages and limitations, and they have often been used for determining microphytobenthos production, but seldom simultaneously (Revsbech et al. 1981, Bott et al. 1997). In the Westerschelde estuary, microphytobenthos production rates show variability at seasonal and hourly scales (Kromkamp et al. 1995), and the annual estimate available so far is based on chlorophyll measurements (De Jong \& De Jonge 1995), not on actual production measurements. This precludes the construction of accurate organic carbon budgets.

We have chosen to work with 2 sediment types differing in grain size distribution, euphotic zones and tidal energy to gain a better understanding of the factors affecting and limiting intertidal microphytobenthic production.

\section{MATERIAL AND METHODS}

The Westerschelde is a macrotidal estuary located in the SW Netherlands (Fig. 1). Tidal flats occupy an important part of its area $(20 \%)$, where microphytobenthos represents the main input of organic carbon to the sediments. A diverse assemblage of benthic microalgae also constitutes a large amount of biomass (Sabbe 1997). The composition of the microbenthic community changes during the year, mainly in relation to abiotic factors such as nutrient concentration, temperature and grain size (Barranguet et al. 1997). Two stations were sampled monthly: sediments at Stn A have on average $10 \%$ silt, 0.07 weight $\%$ organic $C$ and are exposed to a high level of tidal energy; Stn $B$, with a higher percentage of silt $(16 \%)$ and organic $C$ $(0.16$ weight $\%)$, occupies a more elevated and protected part of the flat (Fig. 1).

PAR (photosynthetic available radiation) was measured during the emersion period with a cosine sensor LI 192 (Q 17079) connected to a Licor Data Logger LI1000. Data were integrated every $10 \mathrm{~min}$. Spectral reflectance at the sediments surface was measured with a MACAM SR9910 spectroradiometer on sediment cores exposed to an irradiance level of $800 \mu \mathrm{mol}$ $\mathrm{m}^{-2} \mathrm{~s}^{-1}$ by means of a Schott KL 1500 light source.

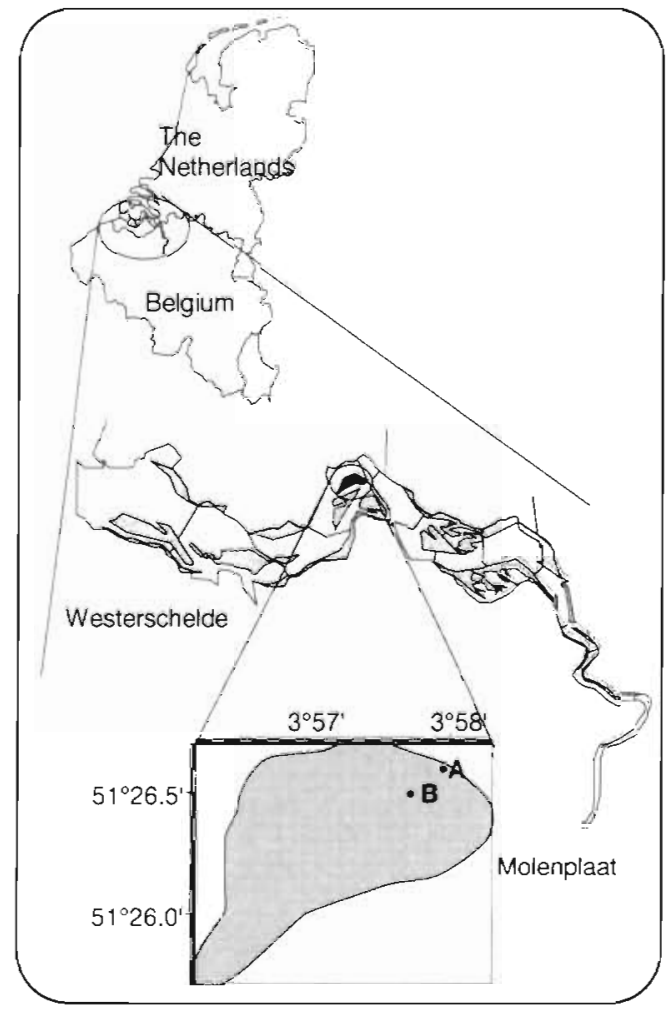

Fig. 1. Study site and location of the stations at the Molenplaat

Temperature was recorded in the field with an RDTemp Omega temperature data logger at 5 min intervals. Samples were always taken during ebb tide (between 3 and 5 h of emersion) once a month on dates when the minimum water level was around noon. Cores for chlorophyll and production measurements (inner diameter $2.5 \mathrm{~cm}$ ) were taken 3 times during ebb tide. The sediment was extruded from the core in $1 \mathrm{~mm}$ slices with a piston manipulated with a screw, with one whole turn equivalent to $1 \mathrm{~mm}$. The samples for chl $a$ were frozen on board until analyses. Pigments were extracted from freeze-dried samples with methanol $(95 \%)$ buffered with ammonium acetate $(5 \%)$ and were sonicated for $10 \mathrm{~min}$. Chl a was analyzed by HPLC as in Barranguet et al. (1997). The results are

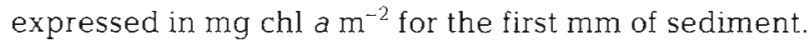

Primary production measurements. Carbon uptake: Microphytobenthic potential production, calculated as ${ }^{14} \mathrm{C}$ bicarbonate uptake, was measured in a photosynthetron (Lewis \& Smith 1983). Duplicate samples were incubated in the dark and at $32,43,91,203,328,614$ and $864 \mu \mathrm{mol} \mathrm{m} \mathrm{m}^{-2} \mathrm{~s}^{-1}$ during the first months, and then at $58,72,154,332,614,1038,1536 \mu \mathrm{mol} \mathrm{m}^{-2} \mathrm{~s}^{-1}$ the rest of the year. Photoinhibition was never observed in any of the measurements.

The incubation procedure followed that of MacIntyre \& Cullen (1995), with small modifications. The 
superficial $\mathrm{mm}$ of 2 sediment cores was diluted in $50 \mathrm{ml}$ of filtered sea water, and aliquots of $2.5 \mathrm{ml}$ were taken while the sample was agitated, producing a homogeneous slurry. The aliquots were placed in glass scintillation vials and $50 \mu \mathrm{l}$ of $\mathrm{NaH}^{14} \mathrm{CO}_{3}$ (Amersham) was added to each sample for a final activity of $0.0185 \mathrm{MBq}$ $\mathrm{ml}^{-1}$. The samples were incubated at in situ temperature. When an increase in sediment temperature was measured during emersion, the temperature was adjusted in the incubator. The carbon incorporation was stopped with $100 \mu$ l of concentrated $\mathrm{HCl}$, which removes all the non incorporated inorganic carbon, as proved by dark and control incubations. The incubation time was short ( $30 \mathrm{~min}$ ) so as to obtain production values as close as possible to gross production (Williams 1993). The samples were counted using a Beckman LS 5000TD scintillation counter including quenching correction, after the addition of $17.5 \mathrm{ml}$ of Dynagel (Baker Analyzer Reagent).

The values of production for each light intensity (2 replicates), expressed per unit area ( $\mathrm{mg} \mathrm{C} \mathrm{m}^{-2} \mathrm{~h}^{-1}$ ), were normalized for chlorophyll units and fitted according to 5 different models for primary production. The model with the best fits (Platt \& Jassby 1976) was adopted to calculate the photosynthetic parameters $\alpha^{\mathrm{B}}$. $P_{\max }^{\mathrm{B}}$ and $I_{k}, \alpha^{\mathrm{B}}$ is the initial slope of the P-I curve (photosynthesis rate at sub-saturating light, in $\mathrm{mg} \mathrm{C} \mathrm{mg}$

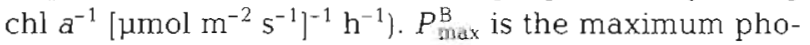
tosynthethic capacity at saturating irradiances ( $\mathrm{mg} \mathrm{C}$ mg chl $\left.a^{-1} \mathrm{~h}^{-1}\right) . I_{k}\left(\mu \mathrm{mol} \mathrm{m}^{-2} \mathrm{~s}^{-1}\right)$, the light saturation parameter, is calculated as $P_{\max }^{\mathrm{B}} / \alpha^{B}$ and is normally used as a photoacclimation index.

To calculate production for the whole photic zone, attenuation between 400 and $700 \mathrm{~nm}$ in the first $\mathrm{mm}$ of sediment was measured with reconstituted sediment as in MacIntyre \& Cullen (1995), assuming an exponential decrease of light intensity in the sediments, according to the formula:

$$
I_{z}=I_{0} \cdot \mathrm{e}^{-k z}
$$

Although scatter may cause an increase of light in the first $\mathrm{mm}$ with respect to the exponential model. (Kühl \& Jorgensen 1994), the sediments at the Molenplaat do not have features favorable for a high scatter, like white quartz sands. This is not the only potential error in vertical fine scale: the algal biomass within the first $\mathrm{mm}$ of sediment ( $\mathrm{chl}$ a) is assumed to be constant, while algae stratify vertically in tenth-of-millimetre scales (Taylor \& Paterson 1998).

Incident light intensity was averaged for the $1.5 \mathrm{~h}$ period between each measurement and, with 3 P-I curves, 3 estimates of carbon fixation were obtained per sampling day.

Production was calculated at each depth with a resolution of $0.1 \mathrm{~mm}$ as

$$
P_{z}=\operatorname{chl} a \cdot P_{\text {max }}^{\mathrm{B}} \cdot \tanh \left(\alpha^{\mathrm{B}} \cdot I_{z} / P_{\text {max }}^{\mathrm{B}}\right)
$$

The production at each layer was added up for the whole photic zone, assuming a constant chl a content with depth in the photic zone. Two-way ANOVAs were performed to test the significance of the short-term (hours) and monthly variations of chl a contents, primary production, and photosynthetic parameters $\left(P_{\max }^{B}, \alpha^{B}\right.$ and $\left.I_{k}\right)$ at both stations. To compare these values with oxygen derived values of gross production, the production values were also calculated assuming a constant incident light intensity of $800 \mu \mathrm{mol} \mathrm{m} \mathrm{m}^{-2} \mathrm{~s}^{-1}$.

Oxygen production: Microphytobenthic gross production was measured by oxygen production in sediment cores (i.d. $6 \mathrm{~cm}$ ) at ambient temperature with a fixed irradiance of approximately $800 \mu \mathrm{mol} \mathrm{m} \mathrm{m}^{-2} \mathrm{~s}^{-1}$. The cores were transported to the ship, then successive measurements were made on board during the emersion period. The cores were cooled in the winter to avoid large differences of temperature from those in the field; $\Delta \mathrm{T}$ between the sediments in the field and the core were 1 or $2^{\circ} \mathrm{C}$ only. In March 1996, at Stn B, the difference was $4^{\circ} \mathrm{C}$, and the values of production were corrected.

Oxygen concentration was measured with Diamond glass microelectrodes ( $737 \mathrm{GC}$ Clark Style). The microelectrodes (duplicates) were lowered via an electrically driven micromanipulator connected to a data logger that controlled the light and dark intervals as well as the distance between measurements.

The electrodes were calibrated after each set of measurements, with air saturated water, and the anoxic layer of the cores was calibrated for $0 \%$ oxygen.

Gross production was estimated by the light-dark shift method described by Revsbech et al. (1981) and Revsbech \& Jorgensen (1986): after a steady state in oxygen concentration is reached during illumination, the observed decrease in oxygen concentration during the first seconds of darkness will be equal to the rate of gross photosynthesis. Microphytobenthic production was assessed in steps of $0.2 \mathrm{~mm}$. The obtained results were integrated over the euphotic zone to estimate the total gross primary production. The mean values of several profiles were averaged to get an average hourly production per emersion period.

A photosynthetic quotient $\left(\mathrm{PQ}=\Delta \mathrm{O}_{2} / \Delta \mathrm{C}\right)$ of 1 was used to transform the oxygen values into carbon (Hargrave et al. 1983).

\section{RESULTS}

During the sampling period, incident light intensities ranged from 25 to $1700 \mu \mathrm{mol} \mathrm{m} \mathrm{m}^{-2} \mathrm{~s}^{-1}$ with high seasonal variability and hourly variability due to cloudiness. 

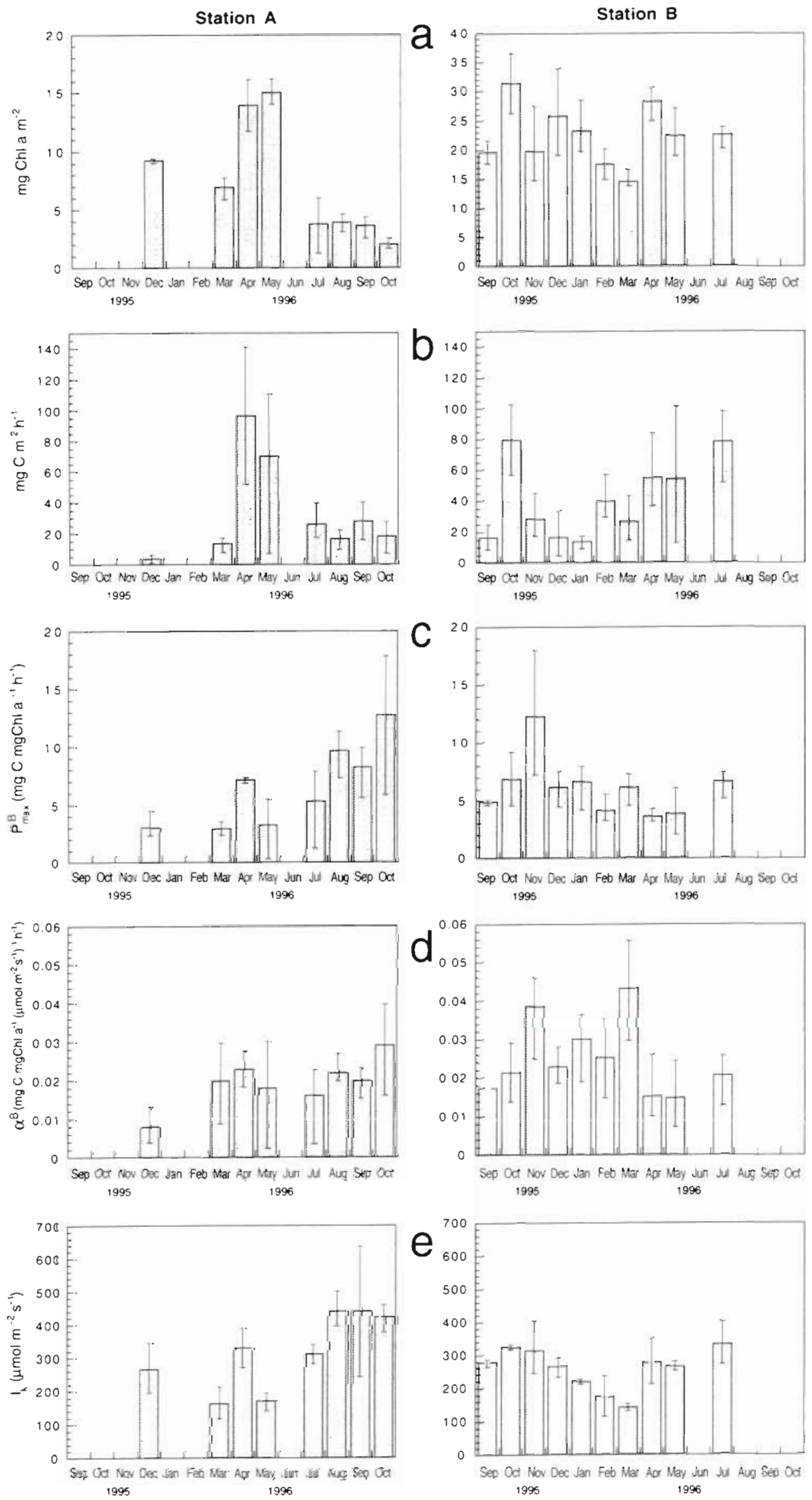

Fig. 2. (a) Chlorophyll a concentrations ( $\mathrm{mg}$ chl a $\mathrm{m}^{-2}$ ) for the superficial $\mathrm{mm}$. of sediment at Stns A and $B$ at the Molenplaat. (b) Hourly rates of microphytobenthos production (mg $\left.\mathrm{C} \mathrm{m}^{-2} \mathrm{~h}^{-1}\right)$ at Stns $A$ and B. (c) $P_{\max }^{\mathrm{B}}$ (the maximum photosynthethic capacity at saturating irradiances/ in $\mathrm{mg} C \mathrm{mg}$ chl $a^{-1} \mathrm{~h}^{-1}$ at Stns $\mathrm{A}$ and B. (d) $\alpha^{\mathrm{B}}$ (photosynthesis rate at sub-saturating light) in $\mathrm{mg} \mathrm{C} \mathrm{mg} \mathrm{chl}^{-1}$ (umol $\left.\mathrm{m}^{-2} \mathrm{~s}^{-1}\right)^{-1} \mathrm{~h}^{-1}$ at Stns A and B. (e) Monthly evolution of the photoac:climation index $I_{k}$ ( $\mu \mathrm{mol}$ $\mathrm{m}^{-2} \mathrm{~s}^{-1}$ ) for microphytobenthos at Stns A and B. Mean values are shown with variation ranges 
Temperature at the sediment surface was also highly variable according to the season, with sharp changes also detected on daily time scales. The minimum was $4^{\circ} \mathrm{C}$ in February 1996 and the maximum temperature recorded was $23^{\circ} \mathrm{C}$ in September 1996. Increases in sediment temperature of $3.5^{\circ} \mathrm{C}$ were recorded during emersion periods on our sampling dates in September and October; in winter, or with cloudy skies, temperatures remained constant at the sediment surface during the whole emersion period.

The calculated depth of the photic zone differed at both stations, due to differences in grain size and silt content and attenuation coefficients showed small variations between the 3 measurements made in March, May and October (1995): $1.98 \pm 0.07$ and $4.24 \pm$ $0.10 \mathrm{~mm}^{-1}$ for Stns A and B respectively.

Microphytobenthos was more abundant at Stn B than at Stn A (annual mean for 1995, $5.9 \pm 3.2 \mathrm{mg}$ chl $a \mathrm{~m}^{-2}$ for the top $\mathrm{mm}$ at $\mathrm{Stn} \mathrm{A}$ and $17.3 \pm 6.7 \mathrm{mg}$ chl $a \mathrm{~m}^{-2}$ for Stn B). A description of the chlorophyll content and microphytobenthic community composition at the eastern part of the Molenplaat was made in Barranguet et al. (1997). The spatial heterogeneity of chl a was less pronounced at Stn A than at Stn B, typical of more agitated sediments. The maximum chl a concentration and primary production were recorded in April and May 1996 for Stn A (Fig. 2). At Stn B, the variability in chl a content during the year was less pronounced and the maximums occurred in October 1995 and April 1996. The classically observed 2 annual peaks in primary production occurred in September 1995 and spring 1996 (March, April and May) (Fig. 2).

Averaging potential hourly production over the entire year $\left({ }^{14} \mathrm{C}\right.$ data), using the recorded incident irradiance, there was no significant difference between rates at both stations (paired $t$-tests, 2 -tailed), with 34.5 $\pm 23.6 \mathrm{mg} \mathrm{C} \mathrm{m}^{-2} \mathrm{~h}^{-1}$ for Stn $\mathrm{A}$ and $41.1 \pm 11.6 \mathrm{mg} \mathrm{C} \mathrm{m}^{-2}$ $\mathrm{h}^{-1}$ for Stn B. At Stn B, the maximum potential production obtained from $C$ fixation measurements $\left(P_{\max }\right.$, not

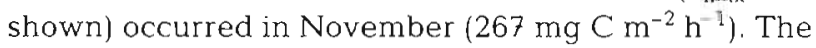
correlation between chl $a$ and $P_{\max }$ was not significant at Stn B. For Stn A, the maximum potential production was recorded in April $\left(119 \mathrm{mg} \mathrm{C} \mathrm{m}^{-2} \mathrm{~h}^{-1}\right)$, and $P_{\max }$ was significantly correlated with $\mathrm{chl} a(\mathrm{r}=0.58 ; \mathrm{n}=23$; $\mathrm{p}<$ $0.01)$.

The photosynthetic activity varied during low tide; however, we could not see any consistent trend in the parameters $P_{\text {max }}^{\mathrm{B}}$ and $\alpha^{\mathrm{B}}$. This is in contrast to results obtained earlier (Kromkamp et al. 1995). The ANOVA tests showed that the short-term variations (hours) of the variables studied (chl $a$, carbon production and photosynthetic parameters $P_{\max }^{\mathrm{B}}, \alpha^{\mathrm{B}}$ and $I_{k}$ ) were not significant for both stations (Table 1).

Nevertheless, production showed consistent seasonal patterns at both stations. Chl a concentrations, carbon production and $P_{\max }^{\mathrm{B}}$ changed significantly at Stn A for the different months sampled, whereas $I_{k}$ and $\alpha^{\mathrm{B}}$ did not (Table 1). $P_{\max }^{\mathrm{B}}$ was positively correlated to temperature $(r=0.588 ; p<0.01)$.

For Stn B, the monthly variations of chl a, carbon production rates and $I_{k}$ were significant (Table 1 ). Both carbon production and $I_{k}$ were correlated with temperature $(\mathrm{r}=0.439, \mathrm{p}<0.05$ and $\mathrm{r}=0.754, \mathrm{p}<0.01$ respectively). These correlations between the photosynthetic parameters and primary production rates and temperature suggest an adaptation of the microphytobenthic communities to the seasonal changes of light and temperature in the silty sediments. Low rates of production were recorded from October to February at Stn B, hinting at a better photoacclimation at Stn B. At Stn B, $I_{k}$ showed seasonal changes, suggesting that algae

Table 1. Analysis of variance for chlorophyll concentrations, carbon production rates and photosynthetic parameters, for Stns A and B. Significant probabilities are underlined

\begin{tabular}{|c|c|c|c|c|c|c|}
\hline & $\mathrm{df}$ & $\begin{array}{l}\text { Month } \\
F \text {-ratio }\end{array}$ & $\mathrm{p}$ & df & $\begin{array}{l}\text { Hour } \\
\text { F-ratio }\end{array}$ & $p$ \\
\hline \multicolumn{7}{|l|}{ Stn A } \\
\hline Chl a $\left(\mathrm{mg} \mathrm{m}^{-2}\right)$ & 7 & 38.84 & 0.000 & 2 & 2.041 & 0.170 \\
\hline Prod. rates $\left(\mathrm{mg} \mathrm{C} \mathrm{m} \mathrm{Cm}^{-2} \mathrm{~h}^{-1}\right)$ & 7 & 3.19 & 0.034 & 2 & 1.79 & 0.206 \\
\hline$P_{\max }^{\mathrm{B}}\left(\mathrm{mg} \mathrm{C} \mathrm{mg} \mathrm{chl} a^{-1} \mathrm{~h}^{-1}\right)$ & 7 & 3.36 & 0.032 & 2 & 0.383 & 0.690 \\
\hline$\alpha^{B}\left(\mathrm{mgC} \mathrm{mg} \mathrm{chl} a^{-1}\left[\mu \mathrm{mol} \mathrm{m} \mathrm{m}^{-2} \mathrm{~s}^{-1}\right] \mathrm{h}^{-1}\right)$ & 7 & 1.53 & 0.247 & 2 & 0.221 & 0.805 \\
\hline$I_{k}\left(\mu \mathrm{mol} \mathrm{m} \mathrm{m}^{-2} \mathrm{~s}^{-1}\right)$ & 7 & 1.22 & 0.362 & 2 & 0.371 & 0.291 \\
\hline \multicolumn{7}{|l|}{ Stn B } \\
\hline Chl a & 8 & 3.02 & $\underline{0.027}$ & 2 & 1.863 & 0.186 \\
\hline Prod. rates & 8 & 3.29 & $\underline{0.018}$ & 2 & 0.309 & 0.738 \\
\hline$P_{\max }^{\mathrm{E}}$ & 8 & 1.54 & 0.214 & 2 & 0.465 & 0.636 \\
\hline$\alpha^{\mathrm{Bax}}$ & 8 & 2.17 & 0.085 & 2 & 0.009 & 0.991 \\
\hline$I_{k}$ & 8 & 4.77 & 0.003 & 2 & 1.689 & 0.214 \\
\hline
\end{tabular}



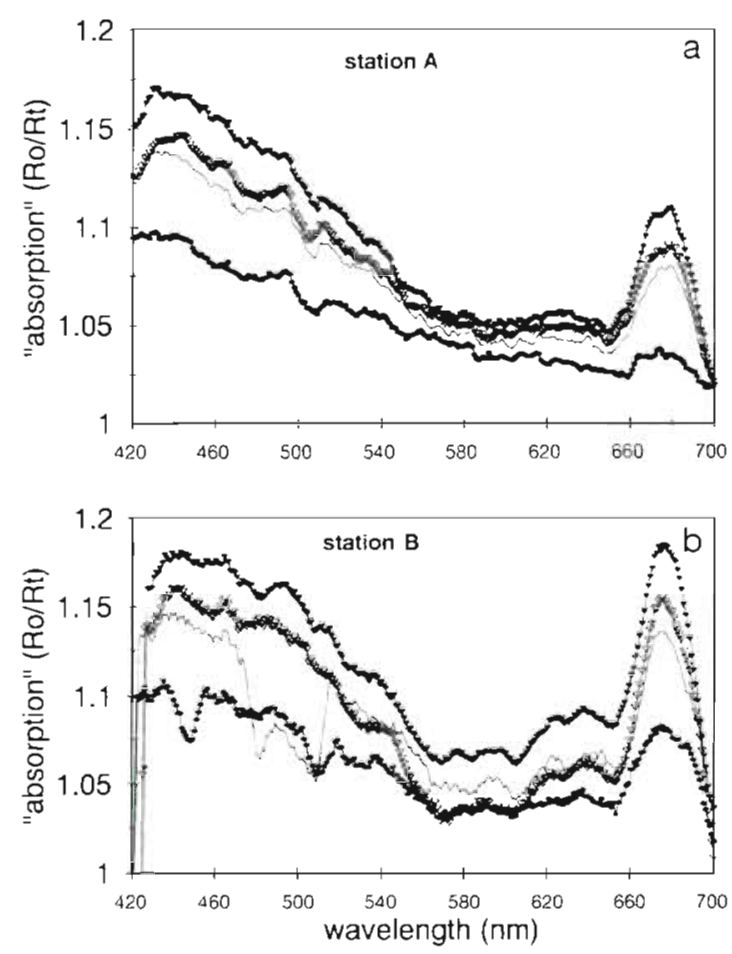

Fig. 3. Spectrum of the light absorbed by the sediments at Stns $A$ and $B$ during different times of low tide (September) showing vertical upwards migration of microphytobenthic algae by continuous increase of absorption at $680 \mathrm{~nm}$. (a) $11: 43 h_{i}-12: 36 h_{i} \nabla 12: 54 h_{i} \nabla 13: 47 h_{\text {. (b) }} \bullet 10: 08 h_{i}$ $10: 38 h_{i} \nabla 12: 08 h_{i} \nabla 12: 38 h$

adapted to the seasonal light conditions (Fig. 2), but there was no significant correlation between the $I_{k}$ and PAR, at any of the stations. Blanchard \& Cariou-Le Gall (1994) also found the same pattern of increasing $I_{k}$ from March to July in muddy sediments as that which we found.

Upward algal migration was detected by the spectroradiometer measurements at both stations from the beginning of emersion onwards. The amount of light absorbed by chlorophyll (around 670 to $680 \mathrm{~nm}$ ) increased sharply during the first hour of emersion (Fig. 3). No significant differences in the change of light absorbed were detected between the 2 stations for the whole emersion period, although the mean $\Delta R$ (reflectance) was higher at Stn B.

The gross production rates calculated with the microelectrodes were often in good agreement with the carbon uptake values, with the only large discrepancies found in periods with the highest production. rates in spring-summer 1996. At this time, gross oxygen production was much higher than the ${ }^{14} \mathrm{C}$ uptake (Fig. 4).

During spring and summer, a station located on a tidal flat in the Oosterschelde was also sampled. The water of the Oosterschelde is much poorer in nitrogen
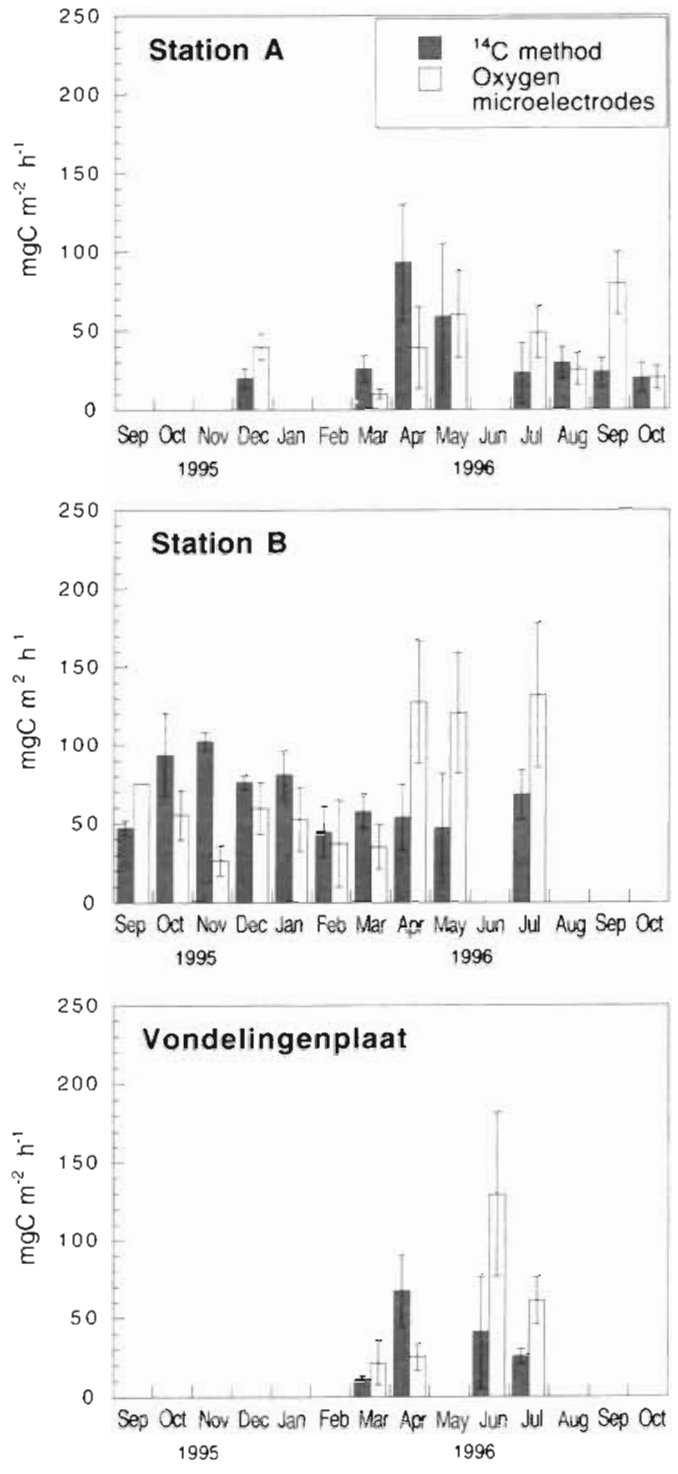

Fig. 4. Gross microphytobenthic production measured with oxygen microelectrodes with an incident light intensity of $800 \mu \mathrm{mol} \mathrm{m}^{-2} \mathrm{~s}^{-1}$ and potential production from the photosynthetic parameters issued from the ${ }^{14} \mathrm{C}$ incubations, calculated for a similar incident light. Stns A and B are located at the Molenplaat in the Westerschelde, and Vondelingenplaat is located in the Oosterschelde

and silicate than that of the Westerschelde (Wetsteyn \& Kromkamp 1994). We also measured oxygen production and carbon uptake to determine any differences in photosynthesis during the periods of maximal productivity that could hint at a nitrogen or silicate limitation during ebb tide. The production rates were slightly lower than in the Westerschelde, and the same discrepancy between oxygen and ${ }^{14} \mathrm{C}$ arose in June for the microphytobenthos in the Oosterschelde (Fig. 4). 


\section{DISCUSSION}

Part of the complexity in attributing changes in microphytobenthos production to seasonal factors can be explained by the mixed microphytobenthic composition of motile and non motile fractions with different ecological strategies. Sabbe (1997) already pointed out the complexity of the microphytobenthic diatom community in the Westerschelde, as temporal patterns are subordinate to spatial ones. He found that the proportion of motile and non motile fractions varied depending on the kind of sediments present and that both fractions had a different seasonal evolution.

In the Molenplaat, the sandy sediments (Stn A) contained proportionally more epipsammic than epipelic algae (Barranguet et al. 1997). The epipsammic fraction is composed of diatoms showing low motility which are firmly attached to the sand grains (De Jonge 1985), and hence more resistant to export, but do not present the functional advantages of the motile fraction, which can vertically migrate in the sediments: migration ensures protection from photoinhibition and desiccation and facilitates access to nutrients and organic and inorganic carbon deeper in the sediments. The spectroradiometer measurements showed vertical algal migration at both stations, but it is difficult to compare quantitatively the amount of the migrating fraction at the 2 stations. First, it is not possible to estimate accurately from which depth the light signal is coming at each of the stations. Second, if the detrital part of the sediment in the beginning of the exposure is already absorbing light in the chlorophyll region, then the normalisation will give lower results of migration than in a sediment without algae. Stn B was richer in degradation pigments of chl $a$ than Stn A. (Barranguet et al. 1997), and the measured change in $R$ at both stations was in the same range, implying that the proportion of migratory algae is larger at Stn B.

The comparison of hourly changes in the photosynthetic parameters during each of the emersion periods studied did not give any additional information regarding a consistent pattern of change at the 2 stations. However, the migration during ebb tide appears to be responsible for the changes in the vertical profiles of production shown in Fig. 5, where the maximum photosynthesis rates progress upwards during the emersion period. ${ }^{14} \mathrm{C}$ calculations of primary production consider the amount of biomass vertically constant in the photic zone, so production will exponentially decrease downwards with decreasing irradiance, without taking into account heterogeneous biomass or vertical migration. In the ${ }^{14} \mathrm{C}$ profile, production decreases exponentially with depth, while in consecutive profiles of oxygen production we see that the maximum production is not located at the surface layer of the sediment but, as also shown by the spectroradiometer measurements, migrates upwards during ebb tide. This could partly explain the discrepancies found between measurements in summer using carbon and oxygen methods. Oxygen profiles show the skewed vertical profile of production, with a maximum biomass located in the subsurface and upward migration during emersion (Fig. 5).

The other reason for a discrepancy between ${ }^{14} \mathrm{C}$ incorporation and oxygen production on those occasions is the apparent wider euphotic zone in the oxygen profiles than the one calculated using the attenuation coefficients of 1995. If there was an enrichment in sand contents in those months, the light intensity penetrating the sediments used to calculate integrated

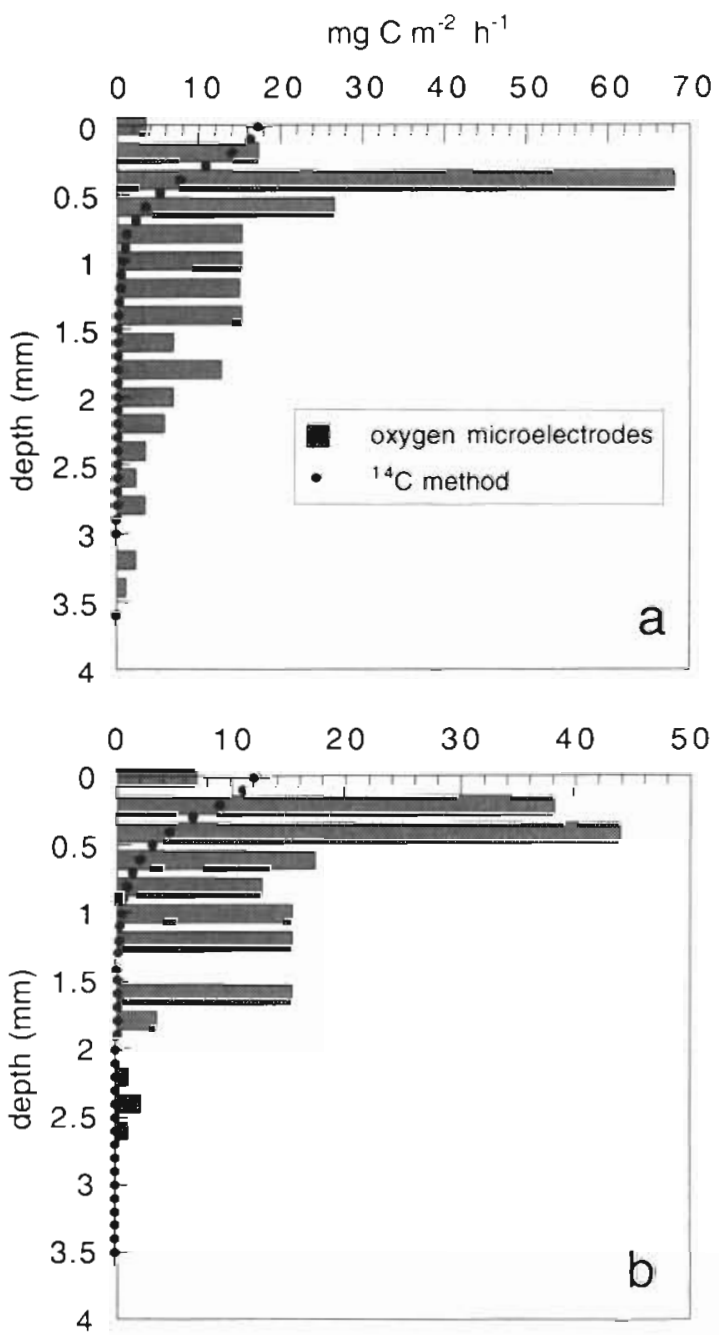

Fig. 5. Vertical profiles of production at Stn B (4 July 1996 ebb tide at $12: 16 \mathrm{~h}$ ) with $800 \mu \mathrm{mol} \mathrm{m} \mathrm{m}^{-2} \mathrm{~s}^{-1}$ incident irradiance, measured with oxygen microelectrodes (bars) with $0.2 \mathrm{~mm}$ resolution and ${ }^{14} \mathrm{C}$ incorporation $(\bullet)$, calculated with $0.1 \mathrm{~mm}$ resolution. (a) Oxygen profile at $10: 20 \mathrm{~h},{ }^{14} \mathrm{C}$ P-I curve started at 10:30 h. (b) Oxygen profile at $12: 45 \mathrm{~h},{ }^{14} \mathrm{C}$ P-I curve started at $12: 30 \mathrm{~h}$ 
production was underestimated, indicating that light attenuation should be measured on each sampling occasion.

For most of the measurements, given the limitations of the 2 very different procedures, there was an acceptable agreement between oxygen and carbon results, suggesting that no marked nutrient limitation occurred at either station. Carbon incorporation values measure potential production, because the algae are resuspended and all the nutrient gradients destroyed, whereas oxygen gross production is measured in intact cores. Therefore, when values measured by the 2 methods are in agreement, as seen in this study, nutrient limitation is not probable. That is, if severe nitrogen or carbon limitation existed, ${ }^{14} \mathrm{C}$ production rates would be much higher than oxygen production measured in an intact core, since during ${ }^{14} \mathrm{C}$ incubations a very small amount of the algae is in contact with an excess of nutrients in the water. Also, nitrate concentration in Westerschelde waters is very high: $185.1 \mu \mathrm{M}$ in June 1996 and an average concentration of $161 \mu \mathrm{M}$ in 1995/96 for the Molenplaat area (Sinke pers. comm.).

However, carbon production rates much higher than oxygen gross production, suggesting a nutrient or carbon limitation, have been observed during spring measurements in very thick mats located in the south of the tidal flat (Barranguet \& Peene 1996), which has a biomass about double that of the northern part. The shape of the P-I curves did not indicate that the microalgae were limited by nutrients or inorganic carbon as there was no decrease in photosynthetic activity during low tide. It can be concluded that under the average concentrations of algal biomass in the Molenplaat, there was no nutrient limitation for microphytobenthic production during the studied period.

Changes in the pattern of photosynthetic parameters during emersion can also be related to environmental factors other than nutrients. Blanchard \& Cariou-Le Gall (1994) found highly variable hourly photosynthetic rates in intertidal. microphytobenthos during March and July in Marennes-Oléron Bay which were attributed to the high adaptive capacity of the algae to short-term variations in field conditions (Blanchard \& Montagna 1992).

Specific adaptation to light and temperature has been often suggested in correlative field studies in intertidal environments (Cadée \& Hegeman 1974, Rasmussen et al. 1983, Grant 1986, Blanchard et al. 1996), as intertidal areas are subject to large fluctuations of temperature, and seasonal increases in temperature are closely accompanied by an increase in PAR. In subtidal environments, microphytobenthos production is more directly linked to light than to temperature (Blanchard \& Montagna 1992, Cahoon \& Cooke 1992, Moncreiff at al. 1992, Barranguet 1997).
Furthermore, photoinhibition is generally not encountered in intertidal microalgae (Cadée \& Hegeman 1974, Cadée 1980, Rasmussen et al. 1983, Colijn \& de Jonge 1984). Some studies on subtidal sediments have, however, shown photoinhibition (Davis \& Macintyre 1983, Sundbäck \& Jönsson 1988, Barranguet 1997). An intermediate situation was described by Gargas \& Gargas (1982) in very shallow sediments $(0.5$ to $0.7 \mathrm{~m})$ where photosynthesis seemed to be regulated by both temperature and light, although temperature was the dominant factor.

In our study, $P_{\max }^{B}$ at $\operatorname{Stn} A$ and $I_{k}$ at $\operatorname{Stn} B$ showed clear seasonal trends, such as a marked correlation with light and temperature, in agreement with the results of Blanchard et al. (1996). MacIntyre \& Cullen (1996) also found a link between $P_{\max }^{\mathrm{B}}$ and temperature in shallow water sediments in San Antonio Bay.

Changes in $P_{\max }^{\mathrm{B}}$ may be explained by changes in algal community composition, which may have varying photosynthetic features: diatoms have a high $P_{\max }^{B}$ when blooming (Kirk 1986) and the microphytobenthic community in the Molenplaat is composed principally of diatoms during the blooming periods of spring and autumn (Barranguet et al. 1997).

The high correlation between $I_{k}$ and temperature and the significant seasonal changes suggests that the main factors regulating microphytobenthic production in the silty sediments were temperature and, indirectly, light conditions. With a narrower euphotic zone, a higher biomass per unit area and no clear nutrient limitation, microalgae at Stn $B$ appeared to be light limited

At $\operatorname{Stn} A$, however, the regulating factors seemed to be of a different nature than at Stn B. Station A is subjected to a high hydrodynamic energy level, resulting in a constant export of microphytobenthic biomass (Barranguet et al. 1997). $P_{\text {max }}^{\mathrm{B}}$ chlorophyll and production rates vary significantly over the year, with biomass and production being correlated. The absence of large fluctuations in $\alpha^{\mathrm{B}}$ and the lesser dependence of $I_{k}$ variance on temperature suggest that the amount of microphytobenthos biomass is determining how much carbon is produced. Resuspension and horizontal transport will result in continuous export of microalgal biomass in sediments at the margins of the Molenplaat, making algal biomass the critical factor lowering production.

Therefore, the factors regulating the production in the 2 types of sediments differed, as did the response of the community. However, the amount of production was of the same order of magnitude in both sediments.

On an annual basis, estimates of intertidal microphytobenthos production fall always around $100 \mathrm{~g} \mathrm{C} \mathrm{m}^{-2}$ $\mathrm{yr}^{-1}$ (Pomeroy 1959, Gargas 1970, Davis \& Lee 1983, Rasmussen et al. 1983, Colijn \& de Jonge 1984, Varela 
\& Penas 1985, Shaffer \& Cahoon 1987, Shaffer 1988, Sullivan \& Moncreiff 1988, Cammen 1991, Steward et al. 1992). The same annual rate of production can be reached by very different mechanisms, resulting in yearly averages which are rather constant. Photosynthesis in microalgae appears to be regulated by very diverse environmental variables; the forcing factors can be as varied as nutrient limitation, light, temperature or sediment grain size and stability.

Our results point to the strong influence of light and sediment stability on microphytobenthos production in the Molenplaat and the important role of migration during ebb tide in determining photosynthesis rates, as well as the bias that can occur in primary production estimations if this process is not considered, especially during periods of high production rates, like blooms, in which biomass is composed mainly of epipelic algae.

Acknowledgements. The computerised micromanipulator for oxygen measurements was designed and constructed at NIOZ (Netherlands Institute for Sea Research). Thanks are due to the crew of the RV 'Luctor' for their valuable assistance in the field. We also thank Dr. P. Herman for discussion of the results and Dr Jack Middelburg and Prof. W. Admiraal for their comments on the manuscript. Jan Sinke is thanked for his assistance with the HPLC. The comments of Prof. V. de Jonge and 2 anonymous referees greatly helped to improve this manuscript. This paper is based on research within the ECOFLAT (Eco-Metabolism of a Tidal Flat) (contract ENV4ct96-0216) project which is part of the ELOISE (European Land-Ocean Interactions Studies) Programme, jointly sponsored by the ENVIRONMENT and MAST programmes of the EU. This is article no. 2337 of the NIOO-CEMO.

\section{LITERATURE CITED}

Barranguet C (1997) The role of microphytobenthic primary production in a Mediterranean mussel culture area. Estuar Coast Shelf Sci 44:753-765

Barranguet C, Herman PMJ, Sinke JJ (1997) Microphytobenthos biomass and community composition studied by pigment biomarkers: importance and fate in the carbon cycle of a tidal flat. J Sea Res 38:59-70

Barranguet C, Peene J (1996) Variations of microphytobenthos photosynthesis during ebb tide in a tidal flat. Book of Abstracts of the ECSA 26 and ERF 96 Meeting, Middelburg, $p 4$

Blanchard GF, Cariou-Le Gall PA (1994) Photosynthetic characteristics of microphytobenthos in Marennes-Oléron Bay, France: preliminary results. J Exp Mar Biol Ecol 182:1-14

Blanchard GF, Guarini JM, Richard P, Gros P, Moret F (1996) Quantifying the short-term temperature effect on lightsaturated photosynthesis of intertidal microphytobenthos. Mar Ecol Prog Ser 134:309-313

Blanchard GF, Montagna PA (1992) Photosynthetic response of natural assemblages of marine benthic microalgae to short-and long-term variations of incidence irradiance in Baffin Bay, Texas. J Phycol 28:7-14

Bott TL, Brock JT, Baattrup-Pedersen A, Chambers PA, Dodds WK, Himbeault KT, Lawrence JR, Planas D. Snyder E, Wolfaardt GM (1997) An evaluation of techniques for measuring periphyton metabolism in chambers. Can $J$
Fish Aquat Sci 54:715-725

Cadée GC (1980) Reappraisal of the production and import of organic carbon in the Western Wadden Sea. Neth J Sea Res 31:147-152

Cadée GC, Hegeman J (1974) Primary production of the benthic microflora living on tidal flats in the Dutch Wadden Sea. Neth J Sea Res 8:260-291

Cahoon LB, Cooke JE (1992) Benthic microalgal production in Onslow Bay, North Carolina, USA. Mar Ecol Prog Ser 84: $185-196$

Cammen LM (1991) Annual bacterial production in relation to benthic microalgal production and sediment oxygen uptake in an intertidal sandflat and an intertidal mudflat. Mar Ecol Prog Ser 71:13-25

Colijn F (1982) Light absorption in the waters of the EmsDollard Estuary and its consequences for the growth of phytoplankton and microphytobenthos. Neth J Sea Res 15:196-216

Colijn F, De Jonge VN (1984) Primary production of microphytobenthos in the Ems-Dollard Estuary. Mar Ecol Prog Ser 14:185-196

Davis MW, Lee H (1983) Recolonization of sediment-associated microalgae and effects of estuarine infauna on microalgal production. Mar Ecol Prog Ser 11:227-232

Davis MW, McIntire CD (1983) Effects of physical gradients on the production dynamics of sediment-associated algae. Mar Ecol Prog Ser 13:103-114

De Jong DJ, De Jonge VN (1995) Dynamics and distribution of microphytobenthic chlorophyll-a in the Western Scheldt estuary (SW Netherlands). Hydrobiologia 311:21-30

De Jonge VN (1985) The occurrence of 'Epipsammic' diatom populations: a result of interaction between physical sorting of sediment and certain properties of diatom species. Estuar Coast Shelf Sci 21:607-622

Gargas E (1970) Measurements of primary production dark fixation and vertical distribution of microbenthic algae in the Oresund. Ophelia 8:321-253

Gargas M. Gargas E (1982) Growth physiological conditions of marine microalgae in the topmost $10 \mathrm{~cm}$ of the sediment. Vatten 38:189-198

Grant $J$ (1986) Sensitivity of benthic community respiration and primary production to changes in temperature and light. Mar Biol 90:299-306

Hargrave BT, Prouse NJ, Phillips GA, Neame PA (1983) Primary production and respiration in pelagic and benthic communities at two intertidal sites in the upper Bay of Fundy. Can J Fish Aquat Sci 40(Suppl 1):229-243

Heip CHR, Goosen NK, Herman PMJ, Kromkamp J, Middelburg JJ . Soetaert K (1995) Production and consumption of biological particles in temperate tidal estuaries. Oceanogr Mar Biol Annu Rev 33:1-149

Kirk JTO (1986) Light and photosynthesis in aquatic ecosystems. Cambridge University Press, Cambridge

Kromkamp J, Peene J, van Rijswijk P, Sandee A, Goosen N (1995) Light, nutrients and primary production by phytoplankton and microphytobenthos in the eutrophic, turbid Westerschelde Estuary (The Netherlands). Hydrobılogia 311:9-19

Kuhl M, Jorgensen BB (1994) The light field of microphytobenthic communities: radiance distribution and microscale optics of sandy coastal sediments. Limnol Oceanogr 39:1368-1398

Lewis MR, Smith JC (1983) A small volume, short-incubation time method for measurements for measurement of photosynthesis as a function of incident irradiance. Mar Ecol Prog Ser 13:99-102

MacIntyre HL, Cullen JJ (1995) Fine-scale vertical resolution 
of chlorophyll and photosynthetic parameters in shallowwater benthos. Mar Ecol Prog Ser 122:227-237

MacIntyre HL, Cullen JJ (1996) Primary production by suspended and benthic microalgae in a turbid estuary: time scales of variability in San Antonio Bay, Texas. Mar Ecol Prog Ser 145:245-268

Macintyre HL, Geider RJ, Miller DC (1996) Microphytobenthos: the ecological role of the 'secret garden' of unvegetated, shallow-water marine habitats. I. Distribution, abundance and primary production. Estuaries 19:186-201

Moncreiff CA, Sullivan MJ, Daehnick AE (1992) Primary production dynamics in sea grass beds of Mississippi Sound: the contributions of seagrass, epiphytic algae, sand microflora, and phytoplankton. Mar Ecol Prog Ser 87: $161-171$

Pinckney J, Zingmark RG (1993) Photophysiological responses of intertidal benthic microalgal communities to in situ light environments: methodological considerations. Limnol Oceanogr 38:1373-1383

Platt T, Jassby AD (1976) The relationship between photosynthesis and light for natural assemblages of coastal marine phytoplankton. J Phycol 12:421-430

Pomeroy LR (1959) Algal productivity in salt marshes of Georgia. Limnol Oceanogr 4:386-397

Rasmussen MB, Henriksen $K_{t}$ Jensen A (1983) Possible causes of temporal fluctuation in primary production of the microphytobenthos in the Danish Wadden Sea. Mar Biol 73:109-114

Revsbech NP, Jørgensen BB (1986) Microelectrodes: their use in microbial ecology. Adv Microb Ecol 9:293-352

Revsbech NP, Jørgensen BB, Brix O (1981) Primary production of microalgae in sediments measured by oxygen microprofile, $\mathrm{H}^{14} \mathrm{CO}_{3}^{-}$fixation, and oxygen exchange methods. Limnol Oceanogr 26:717-730

Sabbe K (1997) Systematics and ecology of intertidal benthic

Editorial responsıbility: Otto Kinne (Editor),

Oldendorf/Luhe, Germany diatoms of the Westerschelde estuary (The Netherlands) Doctoral dissertation, University of Gent

Shaffer GP (1988) A comparison of benthic microfloral production on the West and Gulf coasts of the United States: an introduction to the dynamic K-systems model. Mar Ecol Prog Ser 43:55-62

Shaffer GP, Cahoon CP (1987) Extracting information from ecological data containing high spatial and temporal variability: benthic microfloral production. J Gen Syst 13: $107-123$

Steward C, Pinckney J, Piceno Y, Lovell CR (1992) Bacterial numbers and activity, microalgal biomass and productivity, and meiofaunal distribution in sediments naturally contaminated with biogenic bromophenols. Mar Ecol Prog Ser 90:61-71

Sullivan MJ, Montcreiff CA (1988) Primary production of edaphic algal communities in a Mississippi salt marsh. J Phycol 24:49-58

Sundbäck K, Jönsson B (1988) Microphytobenthic productivity and biomass in sublittoral sediments of a stratified bay, SE Kattegatt. J Exp Mar Biol Ecol 122:63-81

Taylor IS, Paterson DM (1998) Microspatial variation in carbohydrate concentrations with depth in the upper millimetres of intertidal cohesive sediments. Estuar Coast Shelf Sci 46:359-370

Varela M, Penas E (1985) Primary production of benthic microalgae in an interticlal sand flat of the Ria de Arosa, NW Spain. Mar Ecol Prog Ser 25:111-119

Wetsteyn LMPJ, Kromkamp JC (1994) Turbidity, nutrients and phytoplankton primary production in the Oosterschelde (The Netherlands) before, during and after a large-scale coastal engineering project (1980-1990). Hydroblologia 282/283:61-78

Williams PJleB (1993) On the definition of plankton production terms. ICES Mar Sci Symp 197:9-19

Submitted: January 8, 1998; Accepted: July 20, 1998

Proofs received from author(s): October 19, 1998 